\author{
Research Article \\ www.ijrap.net
}

\title{
PHARMACOGNOSTIC EVALUATION OF THE RHIZOME OF COPTIS TEETA WALL.
}

\author{
Namboothiri. D. G. ${ }^{1 *}$, P. Remya ${ }^{2}$, P.P. Bijeshmon ${ }^{3}$
}

${ }^{1}$ General Manager, Research and Development Division, Sreedhareeyam Ayurvedic Research and Development Institute, Koothattukulam, Kerala, India

${ }^{2}$ Deputy Manager, Research and Development Division, Sreedhareeyam Ayurvedic Research and Development Institute, Koothattukulam, Kerala, India

${ }^{3}$ Botanist, Pharmacognosy Laboratory, Sreedhareeyam Ayurvedic Research and Development Institute, Koothattukulam, Kerala, India

Received on: 12/06/14 Revised on: 02/07/14 Accepted on: 11/08/14

\begin{abstract}
*Corresponding author
Mr. D. G. Namboothiri, General Manager (R \& D), Sreedhareeyam Ayurvedic Research \& Development Institute, Nelliakkattu Mana, Koothattukulam - 686662 Ernakulam District, Kerala, India E-mail: dgnamboothiri@sreedhareeyam.com
\end{abstract} DOI: $10.7897 / 2277-4343.05483$

\begin{abstract}
Elaneer kuzhambu and Karpuradi kuzhambu are two ocular preparations referred in Sahasrayoga. According to tradition, Pitaka rohini is added in these preparations. Pitaka rohini is considered as stem bark of Gambhari, Gmelina arborea Roxb. according to Ayurvedic Formulary of India. However according to tradition, Pitaka rohini is considered as Coptis teeta Wall and its rhizomes are used in these preparations. Coptis teeta Wall. is a perennial stemless herb belonging to the family Ranunculacene. HPTLC evaluation of the above two preparations have shown the presence of the active ingredient Berberine. Berberine is present in Daruharidra, Berberis aristata. HPTLC studies showed the presence of Berberine in the rhizomes of Pitaka rohini, Coptis teeta Wall. But Berberine was not detected in the stem bark of Gambhari, Gmelina arborea Roxb. The present study deals with Pharmacognostic evaluation (macroscopic, microscopic, physicochemical, powder microscopy) and HPTLC studies of the rhizomes of Coptis teeta Wall. This study will help in standardization of samples of whole, cut or powdered rhizome samples of Coptis teeta Wall and also help to identify the Berberine content in the rhizomes as well as in the formulations.
\end{abstract}

Keywords: Pitaka rohini, Coptis teeta Wall, Pharmacognostic evaluation, HPTLC.

\section{INTRODUCTION}

Herbal system of medicine has been in practice since historical times and traces its roots to ancient civilizations. Before the availability of synthetic drugs, plant - based remedies formed the basis of primary healthcare system. Herbal infusion, decoction and tinctures were house-hold remedies for common ailments ${ }^{1}$. Elaneer kuzhambu and Karpuradi kuzhambu are preparations referred in Sahasrayoga ${ }^{2}$ for ocular disorders. According to tradition, Pitaka rohini is added in these preparations. Ayurvedic Formulary of India considers stem bark of Gambhari as Pitaka rohini ${ }^{3}$. Gmelina arborea Roxb., is the accepted botanical source of Gambhari, belonging to the family Verbenaceae. This is an important ingredient of the group 'Dasamoola' which enters in to the composition of many of the Ayurvedic formulations. The plant is astringent, bitter, digestive, cardio tonic and laxative. It promotes digestive power, improves memory, overcome giddiness and it is useful in burning sensations ${ }^{4}$. Pitaka rohini used by Ayurvedic Physicians in Elaneer kuzhambu and Karpuradi kuzhambu has been botanically identified as the rhizomes of Coptis teeta Wall. instead of Gmelina arborea. WHO Monographs ${ }^{5}$ describe the use of dried rhizomes of Coptis chinensis Franch, Coptis deliodes, Coptis japonica Makino or other berberine containing species of the same genus. The variety indigenous to India is Coptis teeta Wall. It is a perennial stemless herb, belonging to the family of Rununculacaeae, It is present more commonly in the hilly areas, especially that of the Himalayan region. It is also found in Bhutan, Nepal and China. In India it is found in Assam (Mishmi Mountains),
Arunachal Pradesh, and Sikkim. The plant is $20-50 \mathrm{~cm}$ in height, rhizome is $5-6 \mathrm{~cm}$ long, brownish yellow, densely covered with numerous nodes and often with rootlets. It is used for applying in inflammatory eye diseases, decreased vision, cataract, skin-related problems, indigestion, constipation, jaundice and fever especially in malaria, gonorrhea, and urine disorders ${ }^{6}$. The root is a pungent, very bitter and cooling. The root contains 8-8.5\% berberine, and is widely used as antibacterial, stomachic and anti-inflammatory ${ }^{7}$. Berberine is one of the major active ingredients in the plant. It contains alkaloids like coptine or coptina, fixed oil, albumin, coloring matter, lignin and sugar. Thus it is used widely in ocular ailments in the Ayurvedic system of medicine as a drug of choice and has proved beneficial and $\operatorname{safe}^{8}$. The present study is undertaken with the objective to delineate the pharmacognostical profile of rhizomes of Coptis teeta Wall., as it may assist in standardization of samples of whole, cut or powdered plant material which could guarantee accurate means of identifying the crude drug and also fill the lacuna of our understanding about botanical pharmacognosy of Coptis teeta Wall.

\section{MATERIALS AND METHODS \\ Plant material}

Rhizomes of Coptis teeta Wall. were collected from the raw material store of Sreedhareeyam Ayurvedic Medicines (P) Ltd., Koothattukulam, Kerala, India. The authentic identification of the drug was made by CMPR, AVS, Kottakkal, India and the voucher herbarium specimen (SARDI/SP/92) was prepared and preserved in 
herbarium of Sreedhareeyam Ayurvedic Research and Development Institute (SARDI).

\section{Anatomical studies}

Anatomical studies were carried out ${ }^{9}$. Free hand sections of the rhizomes were taken to study the anatomical features.

\section{Powder microscopy}

The rhizomes of Coptis teeta Wall. were collected, shade dried and powdered. The powder was passed through Sieve No. 60 for obtaining fine powder and that was further subjected to powder microscopy ${ }^{10}$. Photographs were taken with Trinocular digital microscope.

\section{Physicochemical Studies}

The shade dried rhizomes powder was used for the study. Physicochemical parameters like foreign matter, total ash, acid insoluble ash, water soluble extractives and alcohol soluble extractives were determined as per procedures described in the Ayurvedic Pharmacopoeia of India.

\section{HPTLC Studies}

\section{Berberine Standard}

The reference standard berberine was purchased from Sigma Aldrich India

\section{Reference standard 1}

Berberine standard was prepared by dissolving $0.1 \mathrm{mg}$ of berberine in $1 \mathrm{ml}$ methanol. Reference standard 2: Coptis teeta rhizome extract was prepared by refluxing $20 \mathrm{~g}$ powdered rhizome with $50 \mathrm{ml}$ Chloroform for 30 minutes; filtered and evaporated completely by water bath and the residue was dissolved in $1 \mathrm{ml}$ methanol. Reference standard 3: Gmelina arborea stem bark extract was prepared by refluxing $20 \mathrm{~g}$ powdered stem bark with 50 $\mathrm{ml}$ Chloroform for 30 minutes; filtered and evaporated completely by water bath and the residue was dissolved in $1 \mathrm{ml}$ methanol. High performance Thin layer chromatography (HPTLC) was carried out on an Aluminum sheet pre coated with silica gel $60 \mathrm{~F}_{254}$ (E Merck). $5 \mu \mathrm{l}$ of the samples of RS 1,2 and 3 were applied as bands of $8 \mathrm{~mm}$ length using CAMAG HPTLC system equipped with Linomat - V sample applicator. Win cats software was used for interpreting data. The plates were developed to a distance of $80 \mathrm{~mm}$ with Toluene: Ethyl acetate: Formic acid: Methanol (4:4:1:1) as mobile phase in a CAMAG twin trough glass chamber $(20 \mathrm{~cm} \mathrm{x} 10 \mathrm{~cm})$ previously saturated with mobile phase vapor.
Visualization: The plates after running were removed from the chamber, completely dried in air at room temperature and kept in photo documentation chamber and captured images under UV 254 and $366 \mathrm{~nm}$.

\section{RESULTS AND DISCUSSION \\ Morphological characters}

Rhizomes are irregularly cylindrical, 2 to $4 \mathrm{~cm}$ long or rarely up to $10 \mathrm{~cm}$ in length and 0.2 to $0.7 \mathrm{~cm}$ in diameter slightly curved and often branched; rough, grayish yellow or yellowish brown surface, bearing irregular protrusions, rootlets, and rootlet remnants.

\section{Anatomical characters}

Transverse section of the rhizome shows cork layer composed of thin walled cork cells; cortex parenchyma usually exhibiting groups of stone cells near the cork layer and yellow phloem fibers near the cambium; xylem consists of chiefly of vessels trachea and wood fibers; medullary ray distinct; pith large and composed of stone cells. Stone cells with thick and lignified cells are sometimes recognized. Parenchyma cells contain minute starch grains.

\section{Powder characters}

Dark yellowish in color possess no characteristic odor and taste. When treated with chloral hydrate, phloroglucinol and potassium iodide shows the fragments of cork cells, fragments of parenchymatous cells with simple small starch grains and stone cells. Stone cells are seen separately also. Fragments of xylem vessels are found in the powder.

\section{Physicochemical Evaluation}

The Physicochemical parameters obtained for rhizomes of Coptis teeta Wall. are given in Table 1.

\section{HPTLC Studies}

High Performance Thin Layer Chromatography analysis of the extract shows that the rhizome of Coptis teeta (T2) shows the $R_{f}$ value 0.61 , which is similar to that of berberine standard (T1). But the sample of Gmelina arborea (T3) shows no corresponding spots at region showing $\mathrm{R}_{\mathrm{f}}$ values 0.61 . Scanned results also show that the berberine standard peaks at an $\mathrm{R}_{\mathrm{f}}$ range 0.55 to 0.65 . The same peak is shown in rhizome sample Coptis teeta Wall. but there was no corresponding peaks in Gmelina arborea in the same $\mathrm{R}_{\mathrm{f}}$ range.

Table 1: Physico chemical parameters of Coptis teeta Wall.

\begin{tabular}{|c|c|}
\hline Physico chemical parameters & Results \\
\hline Foreign matter & Not more than $0.5 \%$ \\
\hline Total ash & Not more than $3.5 \%$ \\
\hline Acid insoluble ash & Not more than $0.9 \%$ \\
\hline Alcohol soluble extractives & Not less than $16.0 \%$ \\
\hline Water soluble extractives & Not less than $10.0 \%$ \\
\hline
\end{tabular}




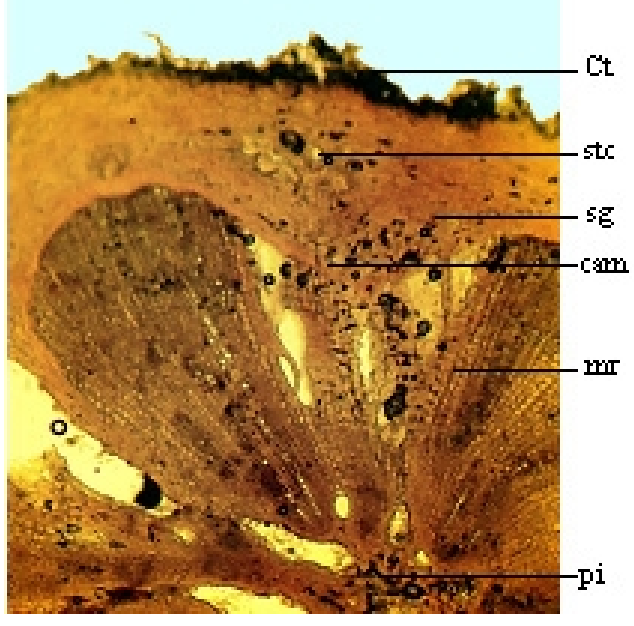

Figure 1: Dried rhizome of Coptis teeta Wall

Ct- Cortex, Stc- Stone cells, Sg- Starch grains, Cam- Cambium, Mr- Medullary rays, Pi- Pith
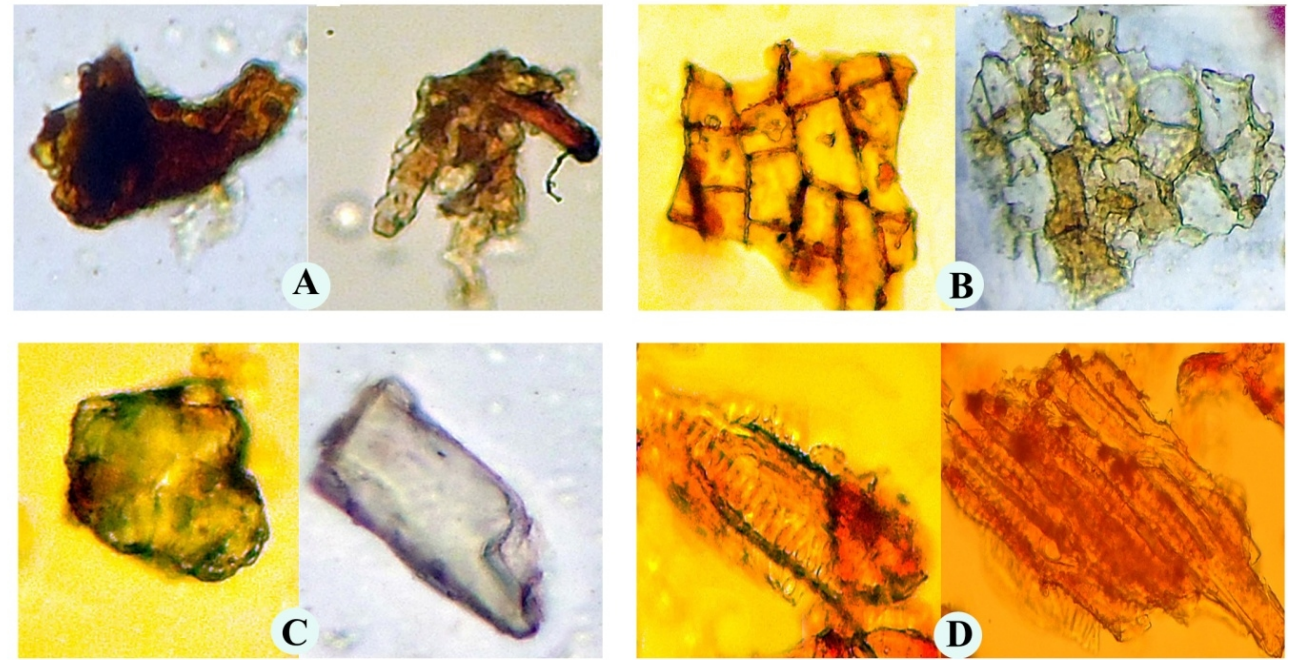

Figure 2: Powder microscopy of Coptis teeta Wall.

Powder microscopy: A- Fragments of cork cells, B- Fragments of parenchymatous cells in surface view, C- Stone cells, D- Xylem vessels

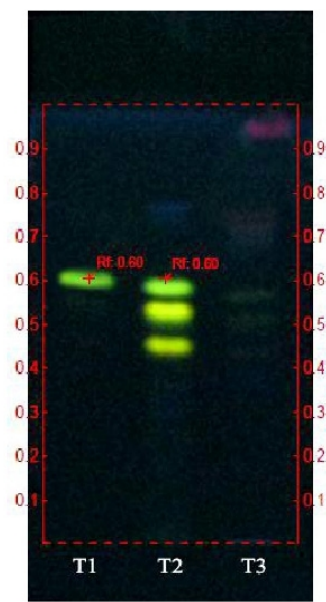

Under UV $366 \mathrm{~nm}$

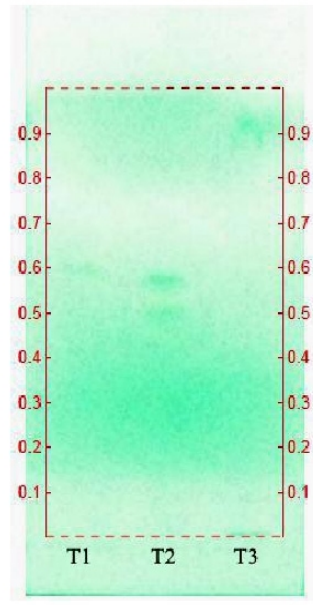

Under UV 366nm

Figure 3: HPTLC Finger print of Coptis teeta and Gmelina arborea with Berberine standard 

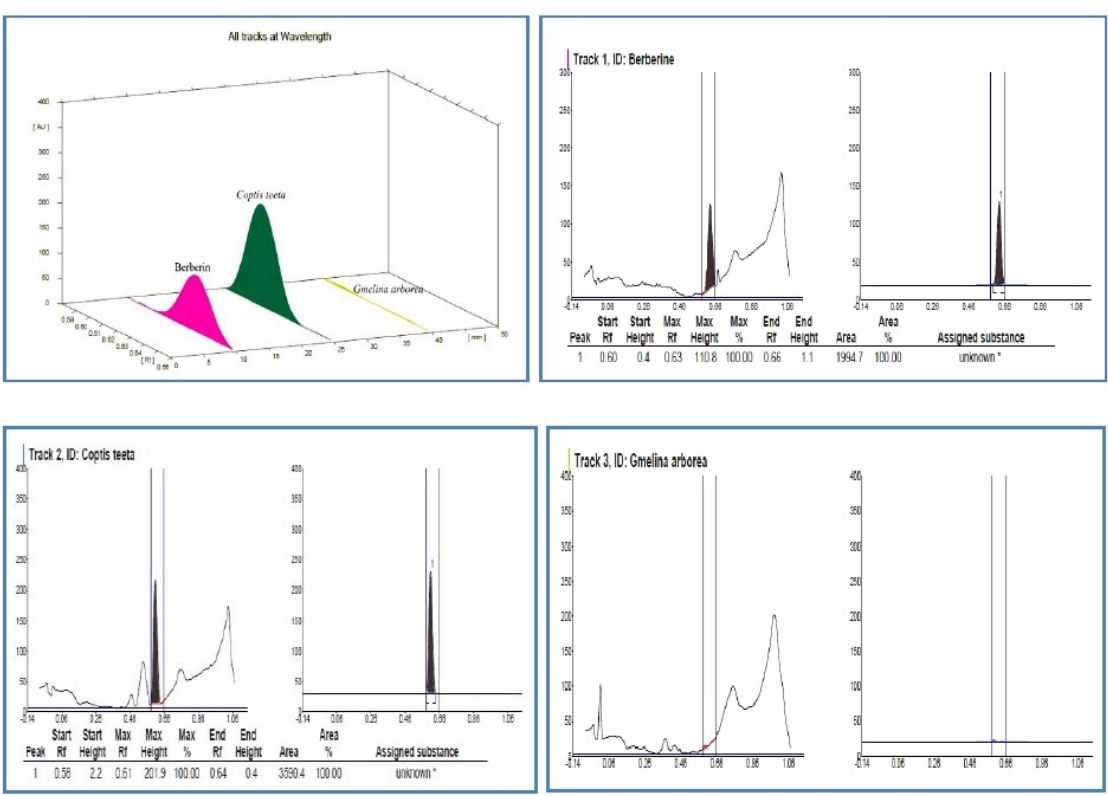

Figure 4: Scanned result of HPTLC Finger print of Coptis teeta and Gmelina arborea and Berberine standard

\section{CONCLUSION}

The present study has shown that the pharmacognostic characters which include morphology, anatomy, powder microscopy and HPTLC studies of the dried rhizome. Berberine is one of the active ingredients in Elaneer Kuzhambu for its medicinal properties. From this study it is clear that the presence of berberine in the rhizomes of Coptis teeta is more prominent than in the stem bark of Gmelina arborea. This study will help in laying down pharmacopoeial standards for Coptis teeta Wall. It is also helpful for the further isolation and identification of phyto-constituents of Coptis teeta Wall. This may be useful to the pharmaceutical industries for the authentification of the commercial samples.

\section{ACKNOWLEDGMENTS}

The authors are grateful to Dr. N.P.P. Namboothiri, Chief Physician and Managing Director Sreedhareeyam Ayurvedic Eye Hospital and Research Centre (P) Ltd., for providing the necessary support.

\section{REFERENCES}

1. Oudhia P. Medicinal herbs of Chhattisgarh, India having less known traditional uses. 135. Rassi Van (Rotula aquatica; family Ehretiaceae). New comments and results of recent Ethnobotanical surveys; 2005.

2. Anonymus, Sahasrayoga, Urdhvangarogacikitsa, Netraroga; Government of India, Ministry of Health and Family Welfare, Department of AYUSH; p. 390.

3. Anonymus, The Ayurvedic Formulary of India, Part - I, II ${ }^{\text {nd }}$ ed, Government of India, Ministry of Health and Family Welfare, Department of AYUSH. New Delhi; 2003. p. 200.

4. Sivarajan VV, Indira Balachandran. Ayurvedic drugs and their plant sources. Oxford and IBH Publishing Co. Pvt. Ltd: New Delhi; 1994. p. 240 .

5. Anonymous, WHO monographs on selected medicinal plants. Vol. 1. World Health Organization Geneva; 1999. p. 105.

6. Arya Vaidya Sala, Kottakkal. Indian Medicinal Plants, Vol. 2, Orient Longman Pvt Ltd; 2007. p. 177.

7. Molony D. Complete guide to Chinese herbal medicine. New York: Berkeley Books; 1998.

8. Babbar OP, Chhatwal VK, Ray IB, Mehra MK. Effect of berberine chloride eye drops on clinically positive trachoma patients. The Indian Journal of Medical Research 1982; 76: 83-8.

9. Johanson A. Plant Micro technique. $1^{\text {st }}$ ed. $3^{\text {rd }}$ impression. McGrawHill book company - INC: New York and London; 1940.

10. Evans WC. Trease and Evans Pharmacognosy $15^{\text {th }}$ edition. Elsevier (A Division of Reed Elsevier India Pvt. Limited); 2002. p. 538-547.

Cite this article as:

Namboothiri. D. G., P. Remya, P.P. Bijeshmon. Pharmacognostic evaluation of the rhizome of Coptis teeta Wall. Int. J. Res. Ayurveda Pharm. 2014;5(4):402-405 http://dx.doi.org/10.7897/2277-4343.05483 